\title{
Pengaruh Pendampingan Orangtua Terhadap Kemandirian dan Tanggung Jawab Anak Selama Belajar dari Rumah
}

\author{
Ratna Pangastuti $^{1}$, Fifi Pratiwi ${ }^{2}$, Alma'atus Fahyuni $^{3}$, Kammariyati ${ }^{4}$ \\ 1,3,4 UIN Sunan Ampel Surabaya \\ ${ }^{2}$ RA Al Amin Kamal Bangkalan Madura
}

\begin{abstract}
The problem in this study is how the influence of parental assistance on children's independence and responsibility while learning from home is seen from parental assistance at $R A A l$ Amien Kamal Bangkalan. This study aims to describe the effect of parental assistance on children's independence and responsibility while learning from home. Our research is using quantitative research. The population of this research is the parents of $B 3$ grade children at RA Al - Amien. Learning in kindergarten or RA schools in this study uses online learning with the guidance of parents and teachers at school. Students do online learning and interact with teachers using the Whatsapp Group application. This study aims to determine the effect of parental assistance on children's independence and responsibility while learning from home. Respondents taken were parents of students in the Perumnas Kamal Bangkalan area. The results showed that parental assistance greatly influences the independence and responsibility of children while learning from home.

Abstrak

Permasalahan di dalam penelitian ini yakni bagaimana pengaruh pendampingan orangtua terhadap kemandirian dan tanggung jawab anak selama belajar dari rumah di lihat dari pendampingan orangtua di RA Al-Amien Kamal Bangkalan. Penelitian ini bertujuan untuk mendeskripsikan pengaruh pendampingan orangtua terhadap kemandirian dan tanggung jawab anak selama belajar dari rumah. Penelitian kami yakni menggunakan penelitian kuantitatif. Populasi penelitian ini adalah orangtua anak kelas B3 di RA Al - Amien. Pembelajaran pada sekolah TK atau RA dalam penelitian ini menggunakan pembelajaran daring dengan bimbingan orang tua dan guru di sekolah. Siswa melakukan pembelajaran daring dan berinteraksi dengan guru menggunakan aplikasi Whatsapp Grup. Penelitian ini bertujuan untuk mengetahui pengaruh pendampingan orangtua terhadap kemandirian dan tanggung jawab anak selama belajar dari rumah. Responden yang di ambil adalah orangtua siswa di wilayah Perumnas Kamal Bangkalan. Hasil penelitian menunjukkan bahwa pendampingan orangtua sangat berpengaruh terhadap kemandirian dan tanggung jawab anak selama belajar dari rumah.
\end{abstract}

DOI : https://doi.org/10.15642/jeced.v2i2.727

\section{Article Info}

Article history:

Received: October 18, 2020

Approved: December 31, 2020

Published online: December 31, 2020

Keywords:

parental assistance

online learning

independence of the child

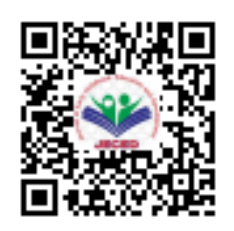

\section{Informasi Artikel \\ Riwayat Artikel}

Diterima: 18102020

Disetujui: 31122020

Publikasi online: 31122020

\section{Kata kunci:}

pendampingan orangtua pembelajaran daring

kemandirian anak 


\section{PENDAHULUAN}

Pandemi COVID-19 adalah suatu musibah yang sangat memilukan dan memberikan dampak bagi seluruh penduduk di berbagai Negara. Seluruh segmen kehidupan manusia di bumi terganggu, tanpa kecuali pendidikan. Banyak negara memutuskan menutup sekolah, perguruan tinggi maupun universitas, termasuk Indonesia. Krisis benar-benar datang tiba-tiba, pemerintah di belahan bumi manapun termasuk Indonesia harus mengambil keputusan yang pahit menutup sekolah untuk mengurangi kontak orang-orang secara masif dan untuk menyelamatkan hidup atau tetap harus membuka sekolah dalam rangka survive para pekerja dalam menjaga keberlangsungan ekonomi. Ada dua yang terdampak Pandemi COVID-19 bagi berlangsungnya dunia pendidikan. Dampak Pertama adalah dampak jangka pendek, yang di rasakan oleh banyak keluarga di Indonesia baik di kota maupun di desa. Di Indonesia banyak keluarga yang kurang familier melakukan sekolah di rumah. Bersekolah di rumah bagi keluarga Indonesia adalah kejutan besar khususnya bagi produktivitas orang tua yang biasanya sibuk dengan pekerjaannya di luar rumah. Demikian juga dengan problem psikologis anak-anak peserta didik yang terbiasa belajar bertatap muka langsung dengan guru-guru mereka. Seluruh elemen pendidikan secara kehidupan sosial "terpapar" sakit karena covid-19. Pelaksanaan pengajaran berlangsung dengan cara online. Proses ini berjalan pada skala yang belum pernah terukur dan teruji sebab belum pernah terjadi sebelumnya. Tak Pelak di desa desa terpencil yang berpenduduk usia sekolah sangat padat menjadi serba kebingungan, sebab infrastruktur informasi teknologi sangat terbatas. Penilaian siswa bergerak online dan banyak trial and error dengan sistem yang tidak ada kepastian, malah banyak penilaian yang banyak di batalkan. Kedua adalah dampak jangka panjang. Banyak kelompok masyarakat di Indonesia yang akan terpapar dampak jangka panjang dari COVID-19 ini. Dampak pendidikan dari sisi waktu jangka panjang adalah aspek keadilan dan peningkatan ketidak setaraan antar kelompok masyarakat dan antar daerah di Indonesia (Rizqon, 2020: 396).

Proses pembelajaran di sekolah merupakan alat kebijakan publik terbaik sebagai upaya peningkatan pengetahuan dan skill (Caroline, 1979:th). Selain itu banyak siswa menganggap bahwa sekolah adalah kegiatan yang sangat menyenangkan, mereka bisa berinteraksi satu sama lain. Sekolah dapat meningkatkan keterampilan sosial dan kesadaran kelas sosial siswa. Seluruh sekolah sebagai media interaksi antar siswa dengan guru guna meningkatkan kemampuan integensi, skill serta rasa kasih sayang mereka. Tetapi sekarang kegiatan yang bernama sekolah berhenti dengan tiba-tiba karena gangguan COVID-19. Bagaimana dampaknya bagi proses pembelajaran di sekolah? Khusus di Indonesia mempunyai banyak bukti di saat sekolah begitu berpengaruh produktivitas dan pertumbuhan ekonomi (Baharin, 2020:139-164).

Kesamaan situasi Indonesia dengan negara-negara lain di belahan dunia mesti segera di atasi dengan seksama. Dalam keadaan normal saja banyak ketimpangan yang terjadi antardaerah. Kementerian Pendidikan di bawah kepemimpinan Menteri Nadiem Makarim, mendengungkan semangat peningkatan produktivitas bagi siswa untuk mengangkat peluang kerja ketika menjadi lulusan sebuah sekolah. Namun dengan hadirnya wabah COVID-19 yang sangat mendadak, maka dunia pendidikan Indonesia perlu mengikuti alur yang sekiranya dapat menolong kondisi sekolah dalam keadaan darurat. Sekolah perlu memaksakan diri menggunakan media daring(Rizqon, 2020:397).

Pendidikan adalah sebuah tanggung jawab bersama bukan hanya pemerintah, tetapi juga sekolah (guru), dan keluarga (orang tua) (Hatimah, 2016: 13). Sekolah bahkan keluarga masuk dalam kelompok primer. Dalam kelompok ini terdapat interaksi sosial yang lebih intensif dan lebih erat, yaitu face-to-face group, dimana setiap anggota dari sebuah kelompok sering menghadapi atau bertatap muka yang satu dengan yang lain, saling memahami dari dekat dan memiliki hubungan yang saling erat. Peranan kelompok primer ini dalam kehidupan individu sangat penting karena di dalam kelompok inilah khususnya keluarga manusia pertama-tama berkembang dan mendapatkan didikan 
sebagai makhluk sosial. Pada kelompok inilah di ajarkan kerangkanya yang kemungkinan guna mengembangkan sifat-sifat sosial, antara lain mengindahkan norma-norma, melepaskan kepentingan dirinya demi kepentingan kelompok sosialnya, belajar bekerja sama dengan yang lainnya, dan mengembangkan kecakapannya guna kepentingan kelompok.

Orang tua pada awalnya berperan dalam membimbing sikap serta keterampilan yang mendasar, seperti pendidikan agama untuk patuh terhadap aturan, dan untuk pembiasaan yang baik (Nurlaeni \& Juniarti, 2017), namun perannya menjadi meluas yaitu sebagai pendamping pendidikan akademik. Prabhawani (2016) menyatakan bahwa pelaksanaan pendidikan merupakan tanggung jawab orang tua dan masyarakat sekitar, tidak hanya tanggung jawab lembaga pendidikan saja. Orang tua adalah bagian dari keluarga yang lebih besar, di gantikan oleh keluarga inti orang tua dan anak-anak. Orang tua memainkan peran penting, mereka sangat berpengaruh dalam pendidikan anak-anak mereka, dan mereka bertanggung jawab atas pendidikan, perawatan dan bimbingan anakanak mereka untuk mencapai tahap-tahap tertentu yang mempersiapkan mereka untuk kehidupan sosial (Agustien, 2020: 549-558).

Salah satu peranan orang tua dalam menanamkan kemandirian adalah dengan membentuk kebiasaan pada anak. Bila anak terbiasa di manja dan selalu di layani, anak akan menjadi pribadi yang menggantungkan orang lain. Kemandirian berkaitan erat sekali dengan sikap disiplin, namun sebelum anak dapat mendisplinkan dirinya maka terlebih dahulu anak harus di siplinkan oleh orang tuanya karena kemandirian pada anak akan terbentuk dari cara orang tua mendidik. Kemandirian anak dapat di lihat sejak anak masih kecil dan akan terus berkembang dalam tahapan-tahapan tertentu sampai akhirnya akan menjadi sifat yang relatif tetap yang harus di dukung pendampingan dari ibu, ayah, dan anggota keluarga lainnya. Dengan memberikan latihan kemandirian sedini mungkin agar anak dapat berkembang sendiri dalam lingkungan dimana dia berada, sehingga anak akan lebih bertanggung jawab baik dalam tingkah laku maupun perbuatannya (Rahmita,2018:116).

Lingkungan yang paling dekat dengan anak-anak untuk menyediakan pendidikan adalah lingkungan yang paling dekat dengan orang tua mereka dan kehidupan mereka, yang memiliki dampak luar biasa pada pertumbuhan dan perkembangan anak. Apabila terdapat kesalahan pengasuhan maka akan berdampak pada anak saat sudah dewasa. Sejalan dengan hal tersebut Rahmawati., (2015) menyatakan bahwa pengasuhan anak merupakan suatu kegiatan berkelanjutan melalui proses interaksi orang tua dan anak untuk mendorong pertumbuhan serta perkembangan anak yang optimal. Terdapat beberapa hal yang dapat di lakukan orang tua untuk meningkatkan tumbuh kembang dan kesehatan anak (asah), yaitu dengan cara: memberi stimulus berupa memberikan cinta yang tulus dan kehangatan, memberi bentuk pengalaman secara nyata dengan menggunakan seluruh indra yang di miliki oleh anak, melakukan interaksi melalui sentuhan, interaksi melalui pelukan, interaksi melalui senyuman, interaksi melalui nyanyian, mendengarkan dengan penuh perhatian menaggapi ocehan anak, mengajak bercakap-cakap dengan suara yang lembut, dan memberi rasa aman (Dariyo., 2004: 17)(Agustien, 2020: 549-558).

Kondisi ketika belajar juga masih jadi tantangan. Terlebih, dalam hal belajar ada anak-anak yang lebih percaya kepada guru di bandingkan dengan orangtua. Ketika keadaan berdiam diri di rumah seperti saat ini, kata dia, mau tidak mau orangtua wajib jadi guru bagi mereka sepenuhnya. Waktu penuh kita harus siap sedia jadi guru dalam keluarga kita. Selain itu, terkait fasilitas juga harus diperhatikan. Apalagi sekarang ini 
berlakunya belajar dengan cara online dari rumah. (Ade Nasihudin Al Ansori, 2020) Namun, fasilitas tersebut akan menjadi kendala bagi anak-anak yang berasal dari keluarga rentan yang memiliki keterbatasan fasilitas. Ketika kesediaan fasilitas ini akan memberi dampak kepada anak sehingga ia mendapatkan nilai tidak baik hingga risiko bullying. Orangtua di haruskan keluar rumah untuk bisa mencari sesuap nasi sehingga anak-anak tidak ada yang mengawasi. Siapa yang mengajari anak-anak belajar. Kondisi seperti itu, membuat anak-anak tersebut juga menjadi rentan terpapar Covid-19 yang saat ini merajalela. Bila di lihat dari segi pengasuhan, orangtua di rumah bisa membuat bingung di karena tugas di rumah jadi bertambah. Mulanya hanya memikirkan bagaimana belanja, masak, serta memberikan hal-hal untuk mempersiapkan anak kita sekolah namun sekarang kita juga harus mendampingi mereka, anak-anak sekarang mungkin punya pemikiran lebih jauh dibanding kita. Seseorang yang ingin sekali mendampingi anaknya jadi sangat bingung, apalagi jika tidak ada yang membantunya. Siapa yang harus membantu kita saat ini (A.Tabi in, 2020: 190-200).

\section{METODE}

Penelitian kami ini dengan menggunakan metode penelitian kuantitatif dengan pendekatan deskriptif. Menurut Sugiyono (2014:7) metode deskriptif di artikan sebagai penelitian yang bermaksud untuk memaparkan data dengan menganalisis data yang di peroleh sehingga mendapatkan gambaran yang jelas. Metode deskriptif kuantitatif adalah metode yang menekankan pada aspek pengukuran secara obyektif terhadap fenomena sosial, penelitian kuantitatif di olah dan di analisis dengan statistik. Jenis metode penelitian yang di gunakan dalam penelitian ini adalah penelitian survey yang berisi butirbutir pernyataan atau item dimana data akan di ambil dari sampel yang telah di tentukan yaitu orangtua anak usia dini. Kemudian data tersebut di pelajari dan di ambil kesimpulan dari hubungan-hubangan antar variabel yang relevan di dalam proses penelitian yang di lakukan. Sampel di ambil sebanyak enam belas responden dengan kriteria yaitu orang tua (ayah atau ibu) yang berada di kelas B3 di RA Al - Amien Kamal, Bangkalan. Variabel bebas dalam penelitian ini adalah pendampingan orangtua, sedangkan variabel terikatnya yakni kemandirian dan tanggung jawab anak.

\section{HASIL PENELITIAN DAN PEMBAHASAN}

Penelitian ini di lakukan di Kelas B3 RA Al Amien Kamal tahun ajaran 2020-2021 pada bulan September 2020. Jumlah responden sebanyak enam belas dari dua puluh wali murid seluruhnya di kelompok B3. Penelitian ini di lakukan dengan memberikan survey kuesioner kepada orang tua melalui Google form yang berisi sepuluh pertanyaan. dengan alamat. https://forms.gle/q6r8R53YVzgGfWX38

Berdasarkan hasil respon angket yang di berikan kepada orang tua melalui Google form di peroleh hasil sebagai berikut: 


\section{Siapa yang mendampingi anak ketika belajar dari rumah berlangsung? \\ 16 tanggapan}

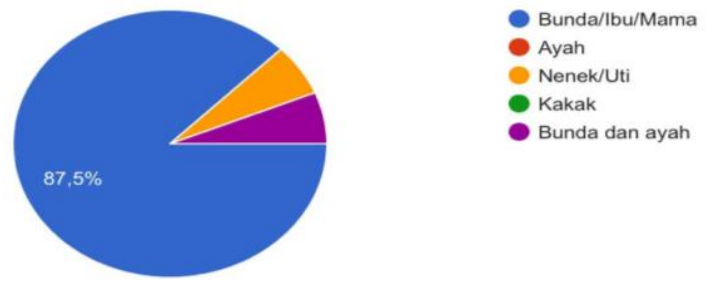

Gambar 1. Pendamping Belajar Anak di Rumah

1. Siapa yang mendampingi anak ketika belajar dari rumah berlangsung? Dari pertanyaan pertama ini jawaban orang tua adalah $87,5 \%$ menjawab di dampingi oleh bunda/ibu/mama, 6,3\% menjawab di dampingi oleh bunda dan ayah dan 6,2\% menjawab di dampingi oleh nenek/uti.
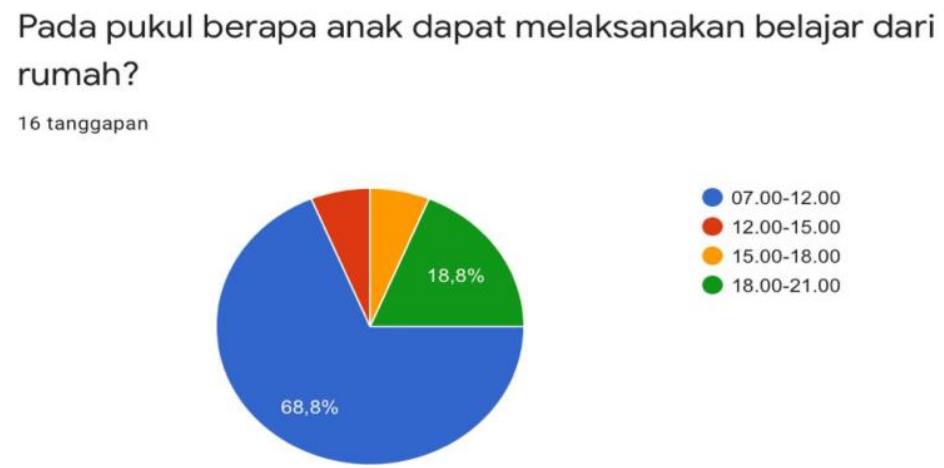

Gambar 2. Waktu Anak Melaksanakan Belajar di Rumah

2. Pada pukul berapa anak dapat melaksanakan belajar dari rumah? Dari pertanyaan kedua ini jawaban orang tua adalah 68,8\% menjawab belajar pada pukul 07:00-12:00 WIB, 18,8\% menjawab belajar pada pukul 18:00-21:00 WIB, 6,2\% menjawab belajar pada pukul 12:00-15:00 WIB dan 6,2\% menjawab belajar pada pukul 15:00-18:00 WIB. 
buat oleh ustadzah membantu anak memahami materi pelajaran?

16 tanggapan

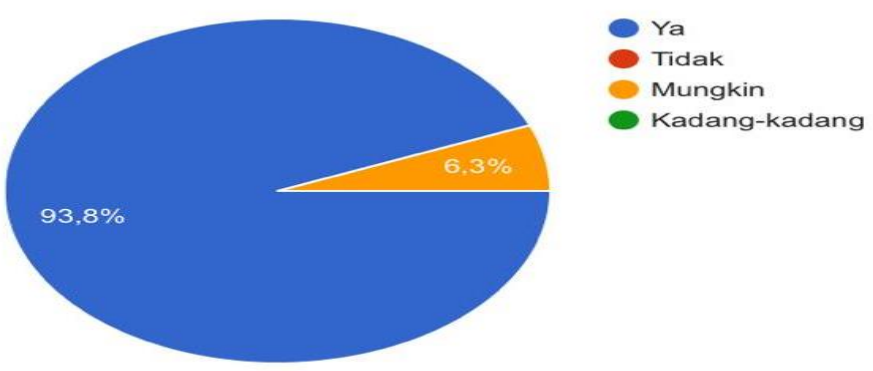

Apakah anak selalu menyimak video pembelajaran yang di berikan oleh ustadzah?

16 tanggapan

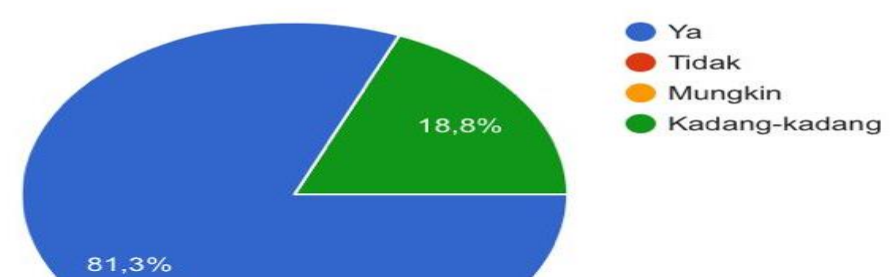

Gambar 4. Tanggapan terhadap Video Pembelajaran

3. Apakah video pembelajaran yang di buat oleh ustadzah membantu anak memahami materi pelajaran? Dari pertanyaan ketiga ini jawaban orang tua adalah 93,8\% menjawab ya dan $6,3 \%$ orang tua menjawab mungkin.

4. Apakah anak selalu menyimak video pembelajaran yang di berikan oleh ustadzah? Dari pertanyaan keempat ini jawaban orang tua adalah $81,3 \%$ menjawab ya dan $18,8 \%$ wali murid menjawab kadang-kadang. 
Apakah anak tetap semangat walaupun belajar dari rumah? 16 tanggapan
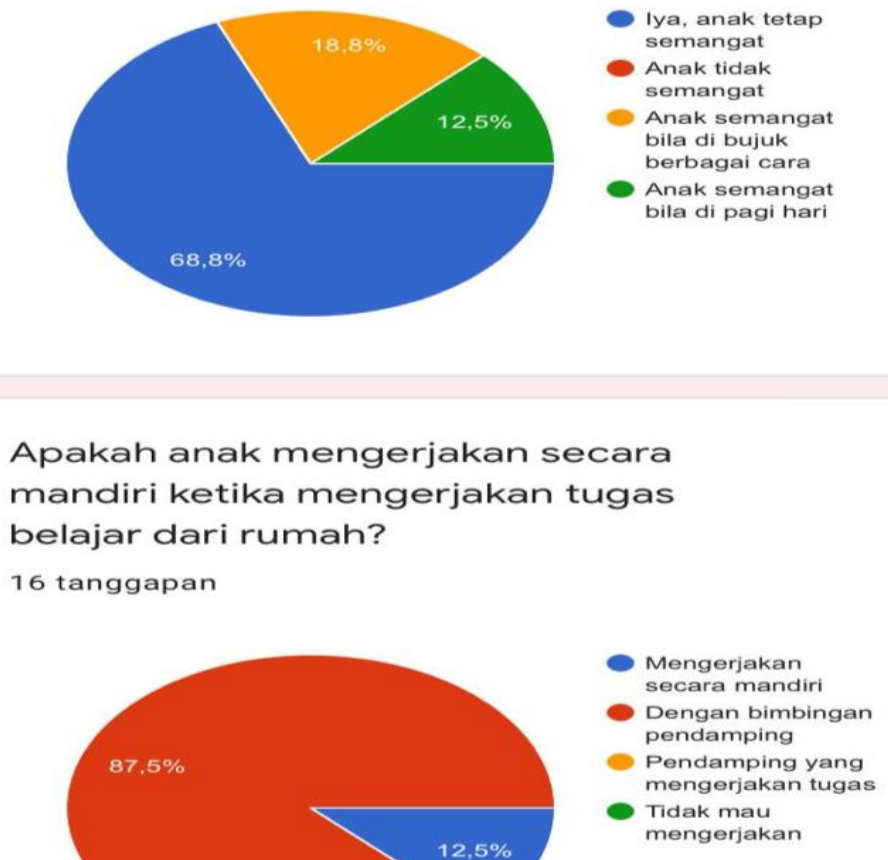

Gambar 5. Cara Anak Belajar di Rumah

5. Apakah anak tetap semangat walaupun belajar dari rumah? Dari pertanyaan kelima ini jawaban orang tua adalah 68,8\% menjawab ya, anak tetap semangat, 18,8\% menjawab anak semangat bila di bujuk berbagai cara dan $12,5 \%$ menjawab anak semangat bila di pagi hari.

6. Apakah anak mengerjakan secara mandiri ketika mengerjakan tugas belajar dari rumah? Dari pertanyaan keenam ini jawaban orang tua adalah $87,5 \%$ menjawab dengan bimbingan pendamping dan $12,5 \%$ menjawab mengerjakan secara mandiri. 


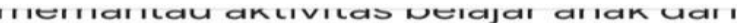 \\ rumah? \\ 16 tanggapan}

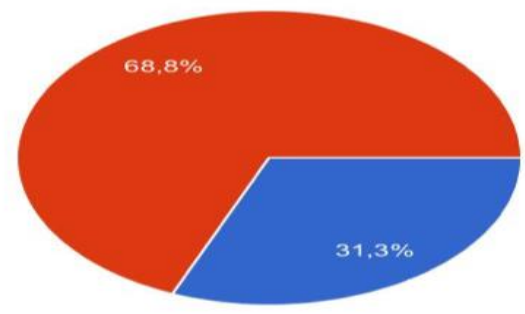

Menanyakan penyelesaian tugas yang dikerjakan anak

Memeriksa tugas yang dikerjakan anak

Tidak memantau aktivitas belajar anak

Berkonsultas dengan anak terkait kendala b.

\section{Apakah yang Anda rasakan ketika menemani anak belajar dari rumah?}

16 tanggapan

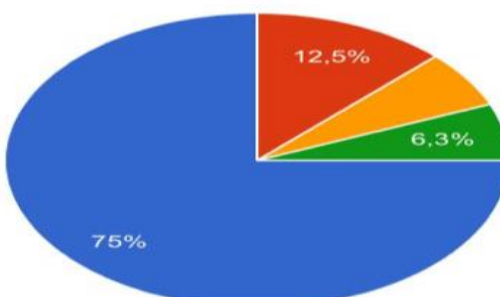

Senang, karena
tau perkembangan
anak secara
langsung
Senang, karena
waktu yang di
luangkan kepada
anak lebih banyak
Sedih, karena tidak
ada waktu untuk
menemani anak
Sedih, karena anak

Gambar 6. Respon Orangtua Ketika Mendampingi Anaknya Belajar di Rumah

7. Apa saja yang anda lakukan dalam memantau aktivitas belajar anak dari rumah? Dari pertanyaan ketujuh ini jawaban orang tua adalah $68,8 \%$ menjawab memeriksa tugas yang di kerjakan anak dan 31,3\% menjawab menanyakan penyelesaian tugas yang di kerjakan anak.

8. Apakah yang anda rasakan ketika menemani anak belajar dari rumah? Dari pertanyaan kedelapan ini jawabn orang tua adalah $75 \%$ menjawab senang, karena tau perkembangan anak secara langsung, 12,5\% menjawab senang, karena waktu yang di luangkan kepada anak lebih banyak, 6,3\% menjawab sedih, karena anak malas belajar dan 6,2\% menjawab sedih, karena tidak ada waktu untuk menemani anak. 
Apakah sekolah/guru berkomunikasi dengan orang tua dalam memantau proses anak belajar dari rumah? 16 tanggapan
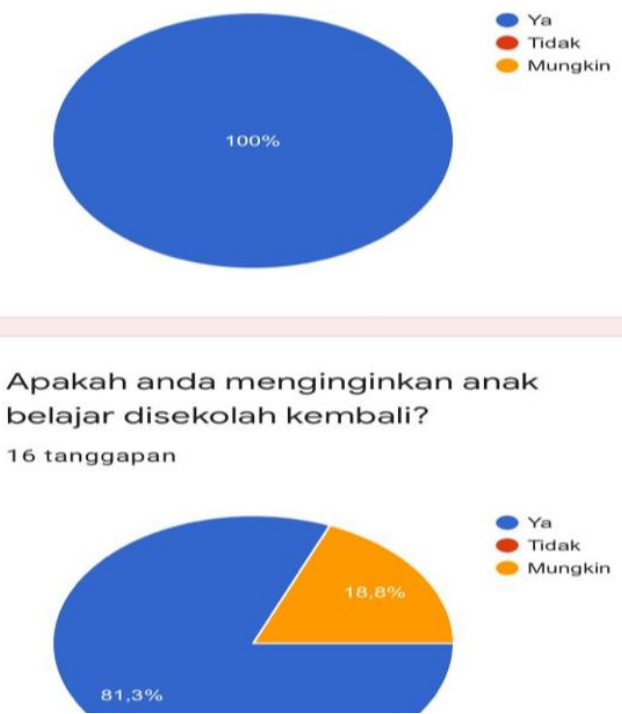

Gambar 7. Komunikasi Sekolah dengan Orantua terhadap Perkembangan Anak selama BDR

9. Apakah sekolah atau guru berkomunikasi dengan orang tua dalam memantau proses belajar dari rumah? Dari pertayaan kesembilan ini jawaban orang tua adalah $100 \%$ ya.

10. Apakah anda menginginkan anak belajar di sekolah kembali? dari pertanyaan kesepuluh ini jawaban orang tua adalah $81,3 \%$ menjawab ya dan $18,8 \%$ menjawab mungkin.

Berdasarkan hasil penelitian yang di lakukan dengan melakukan pengisian kuesioner melalui Google form maka di dapatkan hasil bahwa secara umum selama kegiatan belajar dari rumah kelas B3 RA Al Amien Kamal yang sangat berperan dalam mendampingi anak belajar adalah ibu/mama dengan persentase 87,5\%. Orang tua memiliki tanggung jawab utama dalam proses pertumbuhan dan perkembangan anaknya. Dengan kata lain orang tua menjadi sumber pertama anak untuk belajar karena pada dasarnya anak memiliki dorongan untuk meniru suatu pekerjaan, baik itu dari orang tua maupun dari orang lain yang ada di sekitar lingkungan anak. Baik atau buruknya suatu didikan yang di berikan orang tua akan berpengaruh terhadap perkembangan dan pertumbuhan anak itu sendiri. Hal ini memiliki arti bahwa peran orang tua terhadap anak memiliki banyak sekali kewajiban dan tanggung jawab, salah satunya adalah dalam bidang pendidikan, baik formal maupun non-formal.

Kegiatan belajar anak yang di laksanakan di rumah di sesuaikan dengan kebutuhan anak, selain itu peran orang tua dalam mendampingi anak selama pembelajaran yang di laksanakan di rumah juga sangat penting, namun yang perlu di ingat adalah peran orang tua di rumah bukan untuk menggantikan semua peran guru di sekolah, orang tua hanya menjadi pendamping untuk anak-anak dalam menyampaikan dan melaksanakan kegiatan pembelajaran yang sesuai dengan tugas yang telah di berikan oleh guru di sekolah. Oleh karenanya orangtua di tuntut untuk bersikap lebih sabar dalam membimbing serta mengarahkan anak sebagaimana tugas guru di sekolah sehingga bisa saling melengkapi 
dan membantu memecahkan masalah atau kesulitan yang di hadapi oleh anak-anak selama kegiatan belajar dari rumah.

Banyak orang tua yang merasa senang dengan kegiatan belajar dari rumah karena dapat mempererat hubungan dengan anaknya serta waktu yang diluangkan untuk mendampingi anak belajar lebih banyak dan orang tua juga dapat mengetahui secara langsung bagaimana perkembangan anak dalam belajarnya. Namun tidak semua orang tua senang dengan kegiatan belajar dari rumah ini, karena ada beberapa anak yang kurang semangat dalam belajar selama kegiatan belajar dari rumah, hal ini karena setiap anak memiliki gaya belajar yang berbeda-beda, sehingga orang tua di harapkan dapat mengenal dan memahami gaya belajar anak untuk memudahkan dalam mendampingi anak belajar.

Selama kegiatan belajar dari rumah banyak anak-anak yang memerlukan dampingan orang tua dalam mengerjakan tugas yang di berikan oleh guru di sekolah, terlihat dari hasil kuesioner yang telah di berikan kepada orang tua di kelas B3 RA Al amien Kamal terpadapat $87,5 \%$ orang tua yang menjawab dengan bimbingan pendamping. Namun bukan berarti orang tua yang mengerjakan tugas tersebut, orang tua hanya berperan mendampingi proses belajar anak dan memberikan arahan serta motivasi pada anak agar anak tetap semangat walaupun belajar dari rumah. Hal ini juga dapat membantu anak untuk lebih mandiri dalam mengerjakan tugas dan menjadi peribadi yang lebih mandiri tanpa bergantung pada orang lain dan mengembangkan konsep-konsep yang di perlukan dalam kehidupan sehari-hari agar memudahkanya memahami pekerjaan sehari-hari dan membangun pribadi yang lebih mandiri . Orang tua memiliki peranan penting dalam membantu anak mencapai tugas perkembangannya, yaitu dengan melakukan pendampingan yang tepat dalam menanamkan kemandirian kepada anak yang merupakan salah satu aspek perkembanganya.

Salah satu peranan orang tua dalam menanamkan kemandirian pada anak adalah dengan membentuk kebiasaan pada anak dalam kegiatan sehari-hari. Orang tua pada awalnya berperan dalam membimbing sikap serta keterampilan yang mendasar, seperti pendidikan agama untuk patuh terhadap aturan dan untuk pembiasaan yang baik. Jika anak sudah terbiasa dimanja dan selalu di bantu oleh orang tua, anak akan menjadi pribadi yang bergantung kepada orang lain. Kemandirian berkaitan erat sekali dengan sikap di siplin, namun sebelum anak dapat mendisplinkan dirinya maka terlebih dahulu anak harus di di siplinkan oleh orang tuanya karena kemandirian pada anak akan terbentuk dari cara orang tua mendidik dan mendampingi anak.

Kemandirian anak dapat di lihat sejak anak masih usia dini dan akan terus berkembang dalam tahapan-tahapan tertentu sampai akhirnya akan menjadi sifat yang relatif tetap yang harus di dukung pendampingan dari ibu, ayah, dan anggota keluarga lainnya. Dengan memberikan latihan kemandirian sedini mungkin anak dapat berkembang sendiri dalam lingkungan dimana dia berada, sehingga anak akan lebih bertanggung jawab baik dalam tingkah laku maupun perbuatannya.

Peran orang tua atau orang yang ada di lingkungan sekitar anak dalam membimbing, mengarahkan dan memberi contoh teladan tetap sangat di perlukan, agar anak tetap berada dalam kondisi atau situasi yang tidak membahayakan keselamatannya. Bagi anak-anak, latihan kemandirian ini bisa di lakukan dengan cara melibatkan anak dalam kegiatan praktis sehari-hari di rumah, seperti melatih anak untuk membersihkan kamar tidurnya sendiri, melatih anak menjalankan ibadah sholat lima waktu, dan sebagainya. menanamankan kemandirian pada anak akan menjadi pondasi awal untuk pembentukan karakter mereka, dan media utama yang dapat memberikan contoh dan 
ajaran tentang rasa mandiri tentunya dari pendampingan dan pembiasaan orang tua terhadap anak.

Pendampingan orang tua dalam kegiatan belajar dari rumah ini adalah untuk melatih kemandirian anak, orang tua dapat membiasakan anak dalam mengerjakan tugas secara mandiri namun tetap dalam pantauan dan bimbingannya. Di kelas B3 RA Al Amien Kamal beberapa anak sudah dapat mengerjakan tugas dari guru secara mandiri dan beberapa anak juga mengerjakan tugas secara mandiri akan tetapi masih dengan dampingan orang tua. Untuk meningkatkan kemandirian anak guru juga memberikan kegiatan yang dapat anak lakukan sehari-hari di rumah yang di sesuaikan dengan tema pembelajaran yang di gunakan.

Pendampingan kemandirian dalam belajar anak masih sedang, karena kebanyakan anak masih harus di suruh terlebih dahulu agar mau belajar, bahkan belajar dan durasi belajar juga masih sangat singkat. Orang tua masih kurang memberi perhatian dalam masalah belajar anak, seperti sesekali mengawasi dan menemani anak pada saat belajar. Hal ini terjadi karena orang tua kebanyakan sibuk dengan pekerjaan sehingga kurang memberi contoh serta membiasakan anak untuk melakukan kegiatan secara mandiri tapa bantuan orang lain.

Kemandirian dalam kegiatan belajar adalah anak sudah mampu menyiapkan alat dan buku belajar sendiri tanpa minta bantuan pada orang tua, anak dapat memecahkan masalah nya sendiri dalam belajar seperti dalam mengerjakan tugas dengan sedikitsedikit bertanya pada orang tua, anak dapat berpikir secara kritis, kreatif dan inovatif, memiliki motivasi dan kesungguhan dalam belajarnya dan tetap semangat belajar walaupun kegiatan belajar dari rumah. Dengan pendidikan, anak mendapatkan suatu pencapaian atau bahkan menjadi individu yang siap menghadapi segala tantangan di masa depan.

Dalam memantau aktivitas anak selama belajar dari rumah, orang tua rata-rata memeriksa tugas yang sudah dikerjakan oleh anak serta menanyakan penyelesaian tugas yang di kerjakan oleh anak. Hal ini dilakukan oleh orang tua agar lebih tau kemampuan anak dalam mengerjakan tugas secara mandiri dan membuat anak lebih bertanggung jawab akan penyelesaian tugas yang telah di berikan oleh guru. Orang tua juga mengkomunikasikan pertumbuhan dan perkemabangan anak selama belajar dari rumah dengan pihak sekolah.

Beberapa orang tua berharap anak-anak dapat kembali melaksanakan kegiatan belajar di sekolah kembali, karena beberpa anak kurang bersemangat ketika melaksanakan kegiatan belajar dari rumah yang hanya dilakukan di via grub WhatsApp. Kurangnya interaksi antara peserta didik dengan guru mempengaruhi semangat belajar anak. terlihat dari hasil persentase $81,3 \%$ orang tua berharap kegiatan belajar dapat di laksanakan di sekolah kembali.

Model pembelajaran daring adalah model atau pola pembelajaran pilihan guru untuk merencanakan proses belajar yang sesuai dan efisien guna mencapai tujuan pembelajaran dengan memanfaatkan jaringan komputer dan internet (Yanti et al., 2020,p.56). Model pembelajaran ini juga perlu dirancang dengan baik agar pengalaman belajar peserta didik itu berkesan dan juga dapat mencapai tujuan pembelajaran.

Minat belajar adalah salah satu faktor yang sangat penting untuk keberhasilan belajar yang di miliki siswa, minat muncul dari dalam diri siswa itu sendiri. Faktor dari luar minat belajar yaitu bagaimana cara guru tersebut mengajar. Peran guru sangat penting untuk menumbuhkan minat belajar siswa salah satu dengan cara mengajar yang menyenangkan melalui video pembelajaran, memberikan motivasi yang membangun. 
Pada saat proses kegiatan belajar dari rumah ini anak-anak di dampingi oleh orang tua dan di bantu oleh orang tua. Ada juga yang tidak di dampingi oleh orang tua di karenakan bekerja atau kesibukkan lainnya dan siswa anak-anak melakukan proses pembelajaran daring sendiri dan di dampingi oleh anggota keluarga yang lain seperti nenek atau kakak. Ketika mendapatkan kesulitan dari materi yang di berikan oleh guru, jika tidak di dampingi oleh orang tua anak-anak akan kebingungan dan tidak tau hendak bertanya pada siapa, maka dari itu selama kegiatan belajar dari rumah (BDR) ini di butuhkan dampingan dari orangtua atau anggota keluarga yang lain supaya anak-anak juga semangat dengan belajarnya.

Cara orang tua untuk menumbuhkan minat belajar anaknya dengan selalu memberikan semangat dan mendampingi anak pada saat proses pembelajaran daring berlangsung. Untuk orang tua juga memberikan kenyamanan dalam belajar, tidak selalu memaksa anak dalam belajar dan juga melihat situasi dan kondisi sang anak. Orang tua juga selalu memberikan motivasi kepada anaknya agar tetap belajar dan mengikuti proses pembelajaran meskipun belajar dari rumah. Cara orang tua untuk meningkatkan minat belajar anak salah satunya dengan cara memotivasi anak agar mau mengerjakan tugas sekolah yang di berikan oleh gurunya pada waktu pembelajaran daring sedang berlangsung bisa dengan memberikan hadiah untuk prestasi yang telah di capai agar anak lebih semangat untuk melakukan pembelajaran daring. Pemberian motivasi juga tidak harus memberikan hadiah kepada anak, bisa juga dengan pemberian semangat belajar secara lisan dengan perkataan yang positif dan membangun minat belajar anak itu sendiri. Selalu memberikan motivasi kepada anak bagaimana pentingnya belajar itu sendiri.

Guru memberikan materi pada saat kegiatan belajar dari rumah menggunakan video animasi, cara ini di lakukan untuk menumbuhkan minat belajar siswa dan kegiatan pembelajaran lebih menarik agar anak-anak tertarik pada pembelajaran yang sedang berlangsung. Dan dalam kegiatan belajar dari rumah guru juga menyampaikan motivasi belajar dan semangat untuk belajar meskipun menyapa hanya secara virtual. Selama kegiatan belajar dari rumah guru tidak terlalu menuntut memberikan tugas kepada anakanak hanya saja diberikan beberapa kegiatan yang mudah dan sesuai dengan materi berlangsung.

Dampak kegiatan belajar dari rumah sangatlah besar ketika orang tua kurang kreatif dan inovatif dalam mengatur pola asuh anak. Salah satunya yaitu sikap kemandirian anak. Banyak orang tua yang cenderung memenuhi semua keinginan anak sehingga anak menjadi pasif. Sejak di terapkan kegiatan belajar dari rumah banyak anak yang terbiasa tidak melakukan apa-apa sendiri, semuanya di lakukan orang tuanya dengan dalih kasih sayang orang tua pada anak,hal ini akan menjadikan anak tidak mandiri. Ketidak mandirian otomatis berdampak pada masa depannya. Ketidak mandirian anak terlihat saat anak ketika akan makan, anak memilih disuapi ibu karena ia merasa ada orang tua di sampingnya. Begitu pula dengan kemandirian lainnya memaki baju, padahal ketika harihari di sekolah guru selalu mengajarkan pada anak didiknya untuk melakukan hal-hal sederhana secara mandiri mulai memakai baju atau celana sendiri, membiasakan makan sendiri dan membereskan tempat main sendiri ketika sudah selesai bermain. Semua hal itu saat di rumah peran anak di ambil orang tuanya. Oleh karena itu peran dan pendampingan orang tualah yang menjadi faktor penentu kemandirian anak.

Para orang tua melakukan keterlibatan secara aktif dalam pendampingan belajar, meskipun masih di dominasi oleh para ibu, ayah juga berusaha untuk bergabung dan memberikan pengajaran, pemantauan dan pengawasan di sela-sela kesibukannya mencari nafkah. Pembagian tugas juga di terapkan oleh orang tua sebagai bekal dalam proses pembelajaran mengingat kebijakan pendidikan saat ini mengalami perubahan. Usaha yang di lakukan dengan menambah referensi serta sumber-sumber yang di peroleh 
melalui diskusi antara orang tua untuk mengembangkan potensi anak selama belajar dari rumah dan mendiskusikan kendala yang di alami oleh anak selama kegiatan belajar dari rumah.

Para orang tua juga secara khusus terlibat langsung dalam kegiatan sekolah sehingga bisa mengetahui secara langsung kemajuan pembelajaran anak baik dari segi kognitif, afektif dan fisik motorik melalui pendampingan selama kegiatan belajar dari rumah, diskusi melalui grup sosial media dengan pihak sekolah yang sifatnya wajib untuk menyampaikan perkembangan dan permasalahan yang di hadapi selama menjadi pendamping anak belajar dari rumah. Selain itu orang tua juga menyampaikan kepada pihak sekolah terkait perkembangan anak selama belajar dari rumah apakah berkembang dengan baik dan sudah dapat mengerjakan tugas secara mandiri serta bertaggung jawab atas dirinya sendiri. Hal ini di lakukan untuk meningkatkan prestasi akedemik anak melalui partisipasi dalam mendampingi anak selama kegiatan belajar dari rumah.

Peran orang tua selama kegiatan belajar dari rumah ini sangat penting, karena orang tua di sarankan untuk kegiatan belajar dari rumah. Untuk guru juga di tuntut untuk lebih kretif agar bisa menciptakan pembelajaran yang menarik dan selalu memperhatikan siswa dalam proses kegiatan belajar dari rumah yang berlangsung. Untuk orang tua juga memberikan kenyamanan dalam belajar, tidak selalu memaksa anak dalam belajar dan juga itu melihat situasi dan kondisi sang anak. Dan selalu memberikan perkataan positif dan yang membangun untuk semangat belajar anak, selalu mendampingi anak dalam proses pembelajaran dan membantu anak jika mendapatkan kesulitan dalam proses pembelajaran berlangsung.

Terdapat beberapa hal yang dapat dilakukan oleh orang tua untuk meningkatkan tumbuh kembang dan kesehatan anak (asah), yaitu dengan cara: memberi stimulus berupa memberikan cinta yang tulus dan kehangatan, memberi bentuk pengalaman secara nyata dengan menggunakan seluruh indra yang di miliki oleh anak, melakukan interaksi melalui sentuhan, interaksi melalui pelukan, interaksi melalui senyuman, interaksi melalui nyanyian, mendengarkan dengan penuh perhatian menanggapi ocehan anak, mengajak bercakap-cakap dengan suara yang lembut, dan memberi rasa aman dan selalu melibatkan anak dalam kegiatan sehari-hari yang mudah dan dapat di ikuti oleh anak untuk mengembangkan sikap mandiri dan juga anak dapat bertanggung jawab pada dirinya sendiri.

Antara guru dan orang tua juga harus selalu melakukan komunikasi terkait perkembangan anak, agar guru juga dapat mengetahui perkembangan anak selama kegiatan belajar dari rumah sehingga guru dapat melihat apakah dengan kegiatan belajar dari rumah ini sudah efektif dalam mengembangkan potensi anak dan juga guru dapat menyesuaikan metode dan juga kegiatan apa yang sesuai dengan lingkungan di sekitar anak untuk mempermudah kegiatan belajar dari rumah ini dan anak dapat menikamti dan tetap semangat dalam kegiatan belajar dari rumah karena keberhasilan pembelajaran anak usia dini merupakan tanggung jawab bersama antara guru dan orang tua untuk terwujudnya anak didik yang cerdas dan terampil di tengah masa Pandemi COVID-19.

\section{SIMPULAN DAN SARAN SIMPULAN}

Hasil yang di dapat bahwa pendampingan orang tua dalam menanamkan kemandirian pada anak berada pada kategori baik. Presentase yang di peroleh pada kategori baik sebesar $87,5 \%$ anak sudah dapat mengerjakan tugas dengan bimbingan 
pendamping. Pendampingan di kategorikan baik, karena pada kegiatan mengerjakan tugas anak sudah melakukan secara mandiri hanya saja dengan pendampingan yang semestinya sesuai dengan peran dan tanggung jawab sebagai orang tua. Bukan pendamping yang mengerjakan tugas anak.

Keterlibatan orang tua juga dalam kegiatan belajar dari rumah ini tunjukkan interaksi anatara orang tua dengan pihak sekolah terjalin dengan baik, terutama pada wali kelas anak baik melalui via tatap muka maupun dengan menggunakan alat telekomunikasi Via WhatsApp untuk mengkonsultasikan perkembangan belajar anak serta kendala yang di alami selama kegiatan belajar dari rumah.

\section{SARAN}

Dan orang tua di kelas B3 RA Al Amien Kamal hendaknya lebih memaksimalkan lagi pendampingan dalam menanamkan kemandirian terhadap anak, terutama dalam menanamkan kemandirian dalam mengerjakan tugas yang di berikan oleh guru serta dalam keperluan anak sehari-hari, dan juga yang harus lebih di tingkatkan lagi agar anak tidak hanya mempunyai perilaku mandiri namun juga dapat bertanggung jawab pada diri sendiri. Orang tua juga lebih kreatif dalam mendampingi anak belajar sehingga kegiatan belajar dari rumah dapat terlaksana secara optimal.

\section{AKNOWLEDGMENT}

Penelitian ini didukung oleh biaya mandiri dari tim penulis artikel dan hasil pengabdian kepada masyarakat.

\section{DAFTAR RUJUKAN}

Agoes Dariyo. 2004. Psikologi Perkembangan Remaja. Jakarta: Ghalia Indonesia. Alberta. 1987. Students Thinking: Developmental Cognitive Domain. USA: Alberta Education.

Agustien Lilawati, "Peran Orang Tua dalam Mendukung Kegiatan Pembelajaran di Rumah pada Masa Pandemi ”, Jurnal Obsesi: Jurnal Pendidikan Anak Usia Dini, Volume 5 Issue 1 (2021)

A. Tabi'in, "Problematika Stay At Home Pada Anak Usia Dini Di Tengah Pandemi Covid 19”, Jurnal Golden Age, Universitas Hamzanwadi Vol. 04 No. 1, Juni 2020.

Baharin, R., Halal, R., dll, 2020, Impact of Human Resource Investment on Labor Productivity in Indonesia, Iranian Journal of Management Studies.

Caroline Hodges Persell, 1979, Educations and Inequality, The Roots and Results of Strattification in America's Schools, United States of America: The Free Press.

Heriyanto, H. (2018). Thematic Aanalysis sebagai Metode Menganalisa Data Untuk Penelitian Kualitatif. Anuva, https://doi.org/10.14710/anuva.2.3.317-324 Hurlock, E. (1978). Perkembangan Anak. Jakarta: Erlangga Karnawati, \& Mardiharto. (2020). Sekolah Minggu Masa Pandemi Covid-19: Kendala, Solusi, Proyeksi. Jurnal STT Simpson, 13-24 doi: 10.46445/djce.vli1.291.

Nurlaeni Nurlaeni STKIP Muhammadiyah Kuningan; Yenti Juniarti STKIP Muhammadiyah Kuningan. Vol 2 No 1 (2017): Jurnal Pelita PAUD. Prabhawani, S. W. (2016). Pelibatan Orang Tua Dalam Program Sekolah di TK Khalifah. Jurnal Pendidikan Guru Pendidikan Anak Usia Dini, 2(5)

Sugiyono. (2014). Metode Penelitian Pendidikan Pendekatan Kuantitatif,. Kualitatif, dan R\&D. Bandung: Alfabeta 
Rahmita, Imron A Hakim, Evy Ratna Kartika Waty, "Pendampingan Anak Oleh Orang Tua Dalam Menanamkan Kemandirian Di Desa Sungai Keli Kabupaten Ogan Ilir", 2018.

Rizqon Halal Syah Aji, "Dampak Covid-19 pada Pendidikan di Indonesia: Sekolah, Keterampilan, dan Proses Pembelajaran”, SALAM; Jurnal Sosial \& Budaya Syar-I, Vol. 7 No. 5 (2020).

\section{AUTHOR}
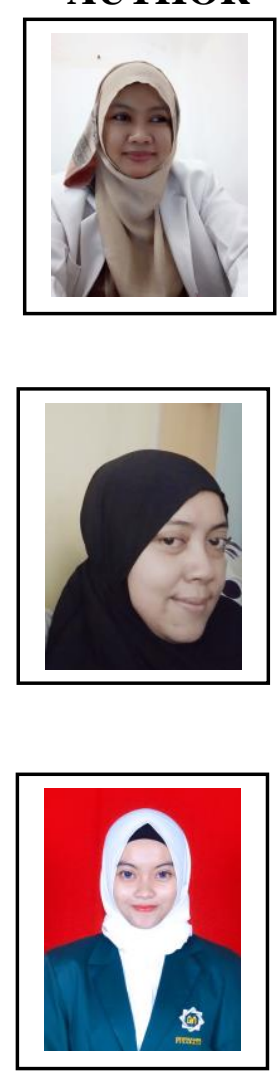

Alma'atus Fahyuni Penulis 3, dilahirkan di Sidoarjo 26 November 1999, ia sedang menempuh pendidikan S-1 UIN Sunan Ampel Surabaya pada Prodi Pendidikan Islam Anak Usia Dini (PIAUD) Fakultas Tarbiyah dan Keguruan (FTK). Sejak tahun 2020, ia menjadi guru di TKM NU 74 Roudlotul Jannah Taman Sidoarjo dan juga guru di TPQ Darul Falah 43. Selain menjadi Mahasiswi dan Guru, ia menjadi Wakil Ketua Angkatan IQMA 2017 UIN Sunan Ampel, ia juga menjadi Ketua IPPNU Pimpinan Ranting di Desa Masangan Kulon selama 2 periode dari 2017-2021, ia juga menjadi Koordinator Departemen Dakwah di PAC Sukodono periode 2019-2021, selain itu ia juga menjadi Anggota HMP PIAUD UIN Sunan Ampel, e-mail: almafahyu@gmail.com.

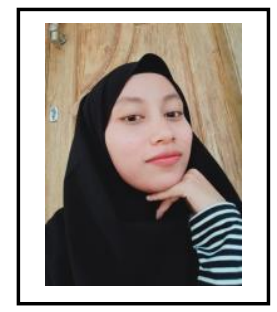

Kammariyati Penulis 4, dilahirkan di Sumenep 05 Maret 1998, ia sedang menempuh pendidikan S-1 UIN Sunan Ampel Surabaya pada Prodi Pendidikan Islam Anak Usia Dini (PIAUD) Fakultas Tarbiyah dan Keguruan (FTK). Sejak tahun 2020, ia menjadi guru di TK Taufiqurrahman Batang-batang Sumenep.

e-mail: kammariyati@gmail.com. 